\title{
Correction to: A common arthropod from the Late Ordovician Big Hill Lagerstätte (Michigan) reveals an unexpected ecological diversity within Chasmataspidida
}

\author{
James C. Lamsdell ${ }^{*}$ (D, Gerald O. Gunderson ${ }^{2 \wedge}$ and Ronald C. Meyer ${ }^{3}$
}

\section{Correction to: BMC Evol Biol (2019) 19:8}

https://doi.org/10.1186/s12862-018-1329-4

Following the publication of the original article [1], it has been brought to the authors' attention that the rights to the minerals and fossils excavated at the site are federally owned by the US Forest Service and are not under the jurisdiction of the Board of Commissioners of Delta County, Michigan. Therefore, future research of the locality will require a federal permit.

\section{Author details}

'Department of Geology and Geography, West Virginia University, 98 Beechurst Avenue, Brooks Hall, Morgantown, WV 26501, USA. ${ }^{2}$ Middleton, USA.

${ }^{3}$ Louiseville, USA.

Published online: 07 June 2021

\section{Reference}

1. Lamsdell JC, Gunderson GO. Meyer RC (2019) A common arthropod from the Late Ordovician Big Hill Lagerstätte (Michigan) reveals an unexpected ecological diversity within Chasmataspidida. BMC Evol Biol. 2019;19:8. https://doi.org/10.1186/s12862-018-1329-4.

The original article can be found online at https://doi.org/10.1186/s12862018-1329-4.

\footnotetext{
*Correspondence: james.lamsdell@mail.wvu.edu

1 Department of Geology and Geography, West Virginia University, 98

Beechurst Avenue, Brooks Hall, Morgantown, WV 26501, USA

Gerald O. Gunderson: Deceased

Full list of author information is available at the end of the article.
}

\section{Publisher's Note}

Springer Nature remains neutral with regard to jurisdictional claims in published maps and institutional affiliations.

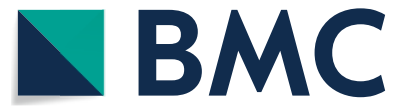

c) The Author(s) 2021. Open Access This article is licensed under a Creative Commons Attribution 4.0 International License, which permits use, sharing, adaptation, distribution and reproduction in any medium or format, as long as you give appropriate credit to the original author(s) and the source, provide a link to the Creative Commons licence, and indicate if changes were made. The images or other third party material in this article are included in the article's Creative Commons licence, unless indicated otherwise in a credit line to the material. If material is not included in the article's Creative Commons licence and your intended use is not permitted by statutory regulation or exceeds the permitted use, you will need to obtain permission directly from the copyright holder. To view a copy of this licence, visit http://creativecommons.org/licenses/by/4.0/. The Creative Commons Public Domain Dedication waiver (http://creativeco mmons.org/publicdomain/zero/1.0/) applies to the data made available in this article, unless otherwise stated in a credit line to the data. 